\title{
APLIKASI BIOFILTER AEROBIK UNTUK MENURUNKAN KANDUNGAN DETERGEN PADA AIR LIMBAH LAUNDRY
}

\author{
Oleh : Bambang Switarto*) dan Sugito ${ }^{*}$
}

\begin{abstract}
Abstrak
Pesatnya pertumbuhan penduduk berpengaruh pada meningkatnya kebutuhan air bersih. Pola kehidupan modern yang serba ingin cepat memicu pertumbuhan ekonomi diantaranya usaha pencucian baju (laundry). Perkembangan usaha laundry menghasilkan air limbah domestik yang mengandung detergen dengan konsentrasi sangat tinggi sehingga mencemari air permukaan. Dampak pencemaran detergen terhadap lingkungan akibat peningkatan usaha laundry harus diatasi. Penelitian ini bertujuan untuk merngkaji aplikasi Biofilter aerobik dengan menggunakan media yang murah untuk mengolah limbah laundry sehingga dapat mereduksi pencemaran air permukaan.

Eksperimen dalam penelitian ini dilakukan dengan menggunakan reaktor Biofilter aerobik aliran upflow. Media yang digunakan untuk pertumbuhan mikroorganisme adalah zeolit, batu apung, dan pecahan genteng ukuran $1 \mathrm{~cm}$ yang dikombinasikan dengan karbon aktif. Sampel air limbah laundry diperoleh dari pengusaha laundry di perumahan. Parameter terukur adalah detergen anionik dengan menggunakan metode Metylena BlueActive Substances (MBAS). Kinerja reaktor Biofilter ditentukan dengan melihat efisiensi penurunan kandungan detergen dan membandingkan variasi media yang digunakan.

Hasil penelitian diperoleh penurunan kandungan detergen pada limbah laundry terbesar terjadi pada reaktor Biofilter dengan media pecahan genteng terpadukan karbon aktif. Efisiensi reduksi maksimum diperoleh rata-rata sebesar $96 \%$ setelah reaktor beroperasi tiga minggu. Pemanfaatan teknologi Biofilter menggunakan media pecahan genteng yang murah terpadukan dengan karbon aktif dapat mereduksi kandungan detergen pada limbah laundry sehingga tidak mencemari air permukaan.
\end{abstract}

Kata kunci : biofilter aerobik, detergen, efisiensi, limbah laundry

\section{PENDAHULUAN}

Air merupakan sumber daya alam yang memenuhi hajat hidup orang banyak sehingga perlu dilindungi agar tetap dapat bermanfaat bagi kehidupan manusia serta makluk hidup lainnya. Pemanfaatan air untuk berbagai kepentingan bagi generasi sekarang dan mendatang sangat perlu diperhatikan sehingga tetap terjaga kuantitas, kualitas, dan kontinuitasnya. Berbagai aktivitas manusia dapat menurunkan kualitas air baik air alami maupun air permukaan. Aktivitas kawasan permukiman merupakan penyumbang terbesar terhadap menurunnya kualitas air permukaan berupa limbah cair domestik.

Pertumbuhan jumlah penduduk di era globalisasi berdampak pada meningkatnya kebutuhan air bersih. Pola kehidupan keluarga modern yang menuntut serba cepat memicu pertumbuhan ekonomi masyarakat. Salah satu usaha yang banyak diminati era sekarang adalah pencucian baju (Laundry) yang tumbuh dengan pesat. Usaha laundry membutuhkan air dalam kuantitas besar dan kualitas yang memenuhi syarat serta terjaga kontinuitasnya agar mesin cuci yang digunakan tidak mudah rusak.

Usaha laundry memberi manfaat yang cukup besar bagi perekonomian masyarakat dalam mengurangi jumlah pengangguran serta dapat meningkatkan taraf hidup manusia. Di sisi lain dengan meningkatnya usaha laundry akan menimbulkan dampak negatif yaitu adanya timbulan limbah cair yang dihasilkan dari sisa proses pencucian baju sehingga berpotensi untuk menimbulkan pencemaran. Detergen sebagai bahan pembersih utama dari usaha laundry sangat potensial menimbulkan efek buruk terhadap lingkungan karena sulit diuraikan oleh mikroorganisme. Hal ini menjadikan limbah deterjen yang dikeluarkan setiap hari oleh rumah tangga/pengusaha akan menjadi limbah berbahaya beracun yang mengancam stabilitas lingkungan hidup.

Dampak fisiologis detergen sebagai surfaktan sintetis adalah berinteraksi dengan membran dan enzim. Pengaruh sedang pada tumbuhan yang menyerap detergen adalah imobilisasi paad dinding sel. Surfaktan dapat menyebabkan perubahan struktur ultraseluler.

*) Alumni Teknik Lingkungan

**)Dosen Teknik Lingkungan

Universitas PGRI Adi Buana Surabaya 
Detergen menyebabkan penghambatan pertumbuhan pada tumbuhan dan ikan, menyebabkan kerusakan pada insang ikan. Surfaktan juga berpengaruh toksik secara akut pada makhluk perairan, (Connel \& Miller, 1995).

Pengaruh lingkungan yang paling jelas adalah menimbulkan busa pada aliran air sungai. Limbah deterjen yang dibuang ke sungai atau rawa akan memicu ledakan pertumbuhan ganggang dan enceng gondok sehingga dasar air tidak mampu ditembus oleh sinar matahari sehingga menyebabkan kadar oksigen menjadi berkurang secara drastis, kehidupan biota air mengalami degradasi, dan unsur hara meningkat pesat. Jika hal seperti ini tidak segera diatasi maka ekosistem akan terganggu dan berakibat merugikan manusia itu sendiri. Kandungan deterjen dalam air minum menimbulkan bau dan rasa tidak enak, dalam jangka panjang air minum yang telah terkontaminasi limbah deterjen berpotensi sebagai salah satu penyebab penyakit kanker (karsinogen).

Limbah laundry mengandung deterjen yang merupakan suatu derivate zat organik, akumulasinya menyebabkan meningkatnya kandungan bahan organik. Kandungan bahan organik dalam air dapat didegradasi dengan proses biologi memanfaatkan mikroorganisme. Salah satu proses biologi untuk mereduksi bahan organik dalam air adalah pengolahan dengan Biofilter. Pada penelitian ini dipilih Biofilter dengan berbagai media yang diharapkan dapat menurunkan kadar deterjen pada air limbah laundry, sehingga pada akhirnya dapat digunakan oleh para pengguna jasa laundry sebelum membuang limbahnya ke sungai.

Permasalahan penelitian ini adalah bagaimanakah menurunkan detergen dalam limbah laundry menggunakan teknologi Biofilter dengan memanfaatkan media penyangga yang murah dan mudah diperoleh. Tujuan penelitian ini adalah mengkaji efisiensi kombinasi penggunaan berbagai media penyangga berupa zeolit, batu apung, pecahan genteng terpadukan media karbon aktif yang digunakan dalam reaktor Biofilter untuk menurunkan kandungan detergen dalam limbah laundry.

Kontribusi pemanfaatan Biofilter dalam penelitian ini yaitu untuk menurunkan kandungan bahan organik khususnya detergen dalam limbah laundry, pemanfaatan media penyangga pertumbuhan mikroorganisme dari bahan berharga murah, dan memperbaiki kualitas air permukaan yang digunakan sebagai air baku air bersih. Selain itu penggunaan teknologi Biofilter oleh pengusaha laundry pada area permukiman akan dapat menyelesaikan masalah limbah cair domestik sehingga dapat menghindari komplain masyarakat yang dirugikan akibat usaha ini.

\section{KAJIAN PUSTAKA}

\section{Pencemaran Limbah Detergen}

Pencemaran air adalah

masukkanya atau dimasukkannya makhluk hidup, zat, energi dan atau komponen lain ke dalam air oleh kegiatan manusia sehingga kualitas air turun sampai ke tingkat tertentu yang menyebabkan air tidak berfungsi lagi sesuai dengan peruntukannya. Komponenkomponen pencemar air terdiri dari komponen fisis, kimia anorganik, kimia organik, dan biologis. Salah satu komponen pencemar kimia organik yang harus diperhatikan adalah detergen yang mengandung bahan aktif surfaktan. Surfaktan (surface active agents) adalah molekul organik dengan massa molekul yang besar larut dalam air membentuk buih dalam pengolahan air limbah sehingga akan mengganggu proses, (Metcalf \& Eddy, 2004).

Surfaktan tersusun atas gugus hidrofobik yang sangat kuat bergabung dengan gugus hidrofilik yang sangat kuat juga. Tipe gugus hidrofobik adalah radikal hidrokarbon $(\mathrm{R}=\mathrm{alkyl})$ yang tersusun oleh 10 sampai dengan 20 atom karbon. Dua tipe gugus hidrofobik yang sering digunakan dapat larut terionisasi ataupun tidak terionisasi dalam air. Surfaktan anionik adalah bermuatan negatif seperti $\left(\mathrm{RSO}_{3} \mathrm{~N}\right)$ $\mathrm{Na}^{+}$, sedangkan surfaktan kationik bermuatan positif seperti $\left(\mathrm{RMe}_{3} \mathrm{~N}\right)^{+} \mathrm{Cl}^{-}$. Surfaktan memiliki berbagai ragam struktur kimiawi dikelompokan menjadi surfaktan anionik, kationok, dan nonionik. Perbedaan ini didasarkan pada sifat gugus polar yang memberiksn sifat khas pada detergen, ( Connel \& Miller, 1995).

Surfaktan nonionik mengandung sebuah gugus polyoksiethylena hidrofobik ( $\mathrm{ROCH}_{2} \mathrm{CH}_{2} \mathrm{OCH}_{2} \mathrm{CH}_{2} \ldots \mathrm{OCH}_{2} \mathrm{CH}_{2} \mathrm{OH}$; gugus $-\mathrm{OCH}_{2} \mathrm{CH}_{2}$ - adalah bersifat hidrofilik). Penggantian komponen detergen dari Alkyl Benzena Sulfonat (ABS) menjadi Alkyl Linier Sulfonat (ALS) sejak tahun 1965 menjadikan bahan ini lebih mudah untuk direduksi karena bersifat biodegradabel, sehingga relatif tidak 
mengganggu dalam proses pengolahan air limbah, (Metcalf \& Eddy, 2004).

\section{Limbah deterjen pada usaha Laundry}

Bahan kimia yang terdapat pada deterjen sangat berbahaya bagi kulit, dapat menimbulkan iritasi. Kadar $\mathrm{pH}$ yang sangat basa (9,5-12) menyebabkan detergen bersifat korosif. Susunan rantai kimia surfaktan terdapat formulasi bahwa semakin panjang dan bercabang rantai surfaktan, akan semakin keras deterjen tersebut. Berdasarkan jenis gugus fungsinya, maka gugus fungsi sulfonat bersifat lebih keras dibandingkan gugus fungsi karboksilat.

Konsentrasi deterjen dihasilkan dari usaha laundry dari proses pencucian baju atau lainnya yang menghasilkan limbah cair. Limbah laundry ini adalah termasuk satu limbah domestik yang apabila dibuang langsung ke badan air dapat menyebabkan pencemaran dan berakibat buruk terhadap lingkungan bila tidak diolah terlebih dahulu..
Sifat fisik limbah laundry ditentukan oleh derajat kekotoran yang mudah dilihat, parameter ini meliputi kandungan zat padat sebagai efek estetika dan kejernihan serta bau, warna dan temperatur. Sifat kimia dalam air limbah dapat menimbulkan bau dan rasa yang tidak sedap. Sifat biologis berdampak pada kehidupan mikroorganisme dan biota di perairanan yang akan berpengaruh pada ekosistem perairan.

Deterjen sebagai bahan utama usaha bisnis laundry merupakan campuran berbagai bahan, yang digunakan untuk membantu pembersihan dan terbuat dari bahan-bahan turunan minyak bumi. Dibanding dengan sabun, deterjen mempunyai keunggulan antara lain mempunyai daya cuci yang lebih baik serta tidak terpengaruh oleh kesadahan air. Detergen merupakan garam Natrium dari asam sulfonat. Reaksi pembentukan detergen seperti pada gambar 1 berikut ini :

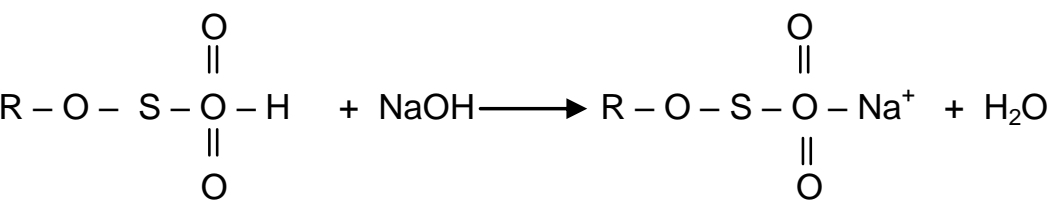

alkil sulfonik Natrium hidroksida Natrium alkil sulfat (deterjen)

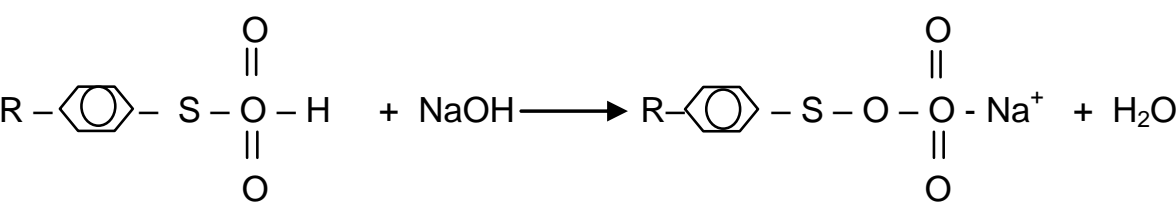

alkilbenzena sulfonik Natrium hidroksida Natrium alkilbenzena sulfonatt (deterjen)

Gambar 1 : Reaksi pembentukan detergen

Rantai hidrokarbon alkil ( $\mathrm{R}$ ) di dalam molekul sabun di atas mungkin adalah rantai hidrokarbon yang lurus atau rantai hidrokarbon yang bercabang, seperti pada gambar 2 dan gambar 3.

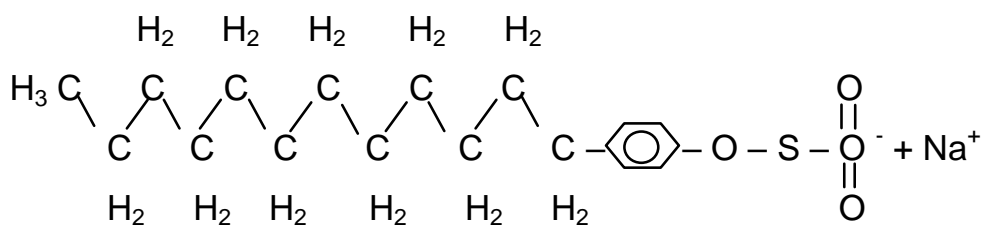

Gambar 2 : Molekul deterjen berantai lurus 
<smiles></smiles>

Gambar 3 : Molekul deterjen berantai bercabang

\begin{abstract}
Surfaktan menahan gugus alkil yang diturunkan dari senyawa minyak bumi. Pada surfaktan anionik terdapat gugus alkil yang terdiri dari 9 sampai 15 atom karbon. Gugus alkil mengandung banyak struktur yang berbeda dan berpengaruh pada proses terjadinya degradasi. Adanya atom karbon kuarterner dalam rantai alkil dapat memperlambat terjadinya proses degradasi, karena sebuah atom hidrogen tidak tersedia bagi oksidasi- $\beta$. Percabangan rantai alkil menghasilkan pertambahan ketahanan terhadap proses biodegradasi. Sebaliknya gugus alkil rantai lurus relatif dapat mudah didegradasi. Hal inilah sehingga secara komersial dikembangkan surfaktan linier (ALS) yang biodegradabel, (Connel \& Muller, 1995).
\end{abstract}

\section{Linier Alkyl Sulfonat (LAS)} merupakan senyawa pengganti Alkyl Benzene Sulfonat (ABS) yang sifatnya sebagai pencemar dan sulit diurai oleh mikroorganisme di permukaan tanah. Pada deterjen LAS yang berfungsi sebagai bahan kimia pengaktif permukaan lebih ramah lingkungan dan memiliki tingkat efektifitas yang lebih tinggi untuk menghilangkan kotoran. Jenis surfaktan yang paling banyak digunakan dalam detergen adalah tipe anionik dalam bentuk sulfat $\left(\mathrm{SO}_{4}{ }^{2-}\right)$ dan sulfonat $\left(\mathrm{SO}_{3}{ }^{-}\right)$.

Peningkatan fungsi detergen
sebagai pembersih biasanya pabrik menambahkan berbagai bahan lainnya seeperti builder, parfum, pemutih, pewangi, pelembut, Natrium Silikat, penstabil, enzim, dan zat lainnya agar fungsinya semakin beragam. Namun zat aditif tersebut ada yang tak bisa dihancurkan oleh mikroorganisme sehingga otomatis menyebabkan pencemaran lingkungan. Apabila air yang mengandung detergen dibuang ke dalam air, maka proses pencemaran air mulai terdistribusi dan menyebabkan eutrofikiasi sangat cepat. Hal ini akan menyebabkan kandungan oksigen dalam air berkurang dan otomatis ikan, tumbuhan laut, dan kehidupan air lainnya mati. Selain itu limbah detergen juga menyebabkan pencemaran tanah yang menurunkan kualitas kesuburan tanah yang mengakibatkan tanaman serta kehidupan tanah termasuk cacing mati.

\section{Teknologi Proses Biofilter}

\begin{tabular}{llr}
\multicolumn{1}{c}{ Biofilter } & adalah & teknologi \\
pengolahan air & limbah dengan \\
memanfaatkan & & pertumbuhan
\end{tabular}

mikroorganime melekat pada suatu media membentuk suatu lapisan biofilm. Proses pengolahan limbah ini terdiri dari paking reaktor, media penyangga, biofilm, dan aliran air limbah. Media berfungsi sebagai tempat tumbuh mikroorganisme membentuk film biologis yang terdiri dari bakteri , jamur, ganggang, dan protozoa. Pengaliran air limbah dalam media penyangga membawa substrat yang berfungsi sebagai bahan makanan mikroorganisme sehingga air limbah terdegradasi menghasilkan biomassa, karbondioksida, dan air. Jenis media yang sering digunakan adalah material yang memiliki permukaan kasar seperti kerikil atau batu kali.

Berbagai tipe variasi proses Biofilter yang telah dikembangkan dapat digunakan untuk mengolah air limbah domestik. Beberapa proses yang telah dikembangkan adalah proses Biocarbon dengan menggunakan material Clay (Perancis), proses Biofor dengan menggunakan material Biolite (Eropa dan Amerika Utara), proses Biostyr dengan media polystyrena (Denmark). Tipe terakhir yang dikembangkan adalah Fluidized- Bed Bioreactors (FBBR) dengan menggunakan media pasir atau karbon aktif (Metcal \& Eddy, 2004). Pengembangan teknologi FBBR di Korea digunakan untuk mengolah air limbah rumah sakit menghasilkan efluen yang sangat baik.

$\begin{array}{ccc} & \text { Media sebagai tempat } \\ \text { pertumbuhan mikroorganisme sangat }\end{array}$ berpengaruh pada efisiensi proses pengolahan. Jenis media filter yang berbeda memberikan luas permukaan total 
specifik yang berbeda dalam reaktor. Kerikil atau batu kali pecah memiliki luas permukaan sekitar $100-200 \mathrm{~m}^{2}$ dapat menurunkan kandungan BOD sampai $95 \%$ digunakan untuk mengolah air limbah domestik (Sugito, 2008), mereduksi sampai 98\% untuk mengolah air limbah puskesmas, (Ifadah \&Sugito, 2012).Dalam penelitian ini akan digunakan media yang murah dan mudah diperoleh bahkan merupakan barang yang tidak digunakan yaitu pecahan genteng, batu apung, dan batu kapur atau zeolit.

Penguraian bahan organik dalam air dilakukan oleh mikroorganisme. Proses metabolisme oleh bakteri dipengaruhi oleh faktor diantaranya adalah :

a. Temperatur, temperatur tidak hanya mempengaruhi aktivitas metabolism dari populasi mikroorganisme, tetapi juga mempengaruhi beberapa factor seperti kecepatan transfer gas dan karakteristik pengendapan lumpur.

b. $\mathrm{pH}$, nilai $\mathrm{pH}$ merupakan factor kunci bagi pertumbuhan mikroorganisme. Beberapa bakteri dapat hidup pada $\mathrm{pH}$ diatas 9,5 dan dibawah 4,0. Secara umum $\mathrm{pH}$ optimum bagi pertumbuhan mikroorganisme adalah sekitar 6,5-7,5.

c. Waktu Tinggal Hidrolisis (WTH) adalah waktu perjalanan limbah cair di dalam reactor, atau lamanya proses pengolahan limbah cair tersebut. Semakin lama waktu tinggal, maka penyisihan yang terjadi pada reactor aerob sangat bervariasi dari 1 jam hingga berhari-hari.

d. Nutrien, disamping kebutuhan karbon dan energy, mikroorganisme juga membutuhkan nutrient untuk sintesa sel dan pertumbuhan. Kebutuhan nutrient tersebut dinyatakan dalam bentuk perbandingan antara karbon dan nitrogen serta phosphor yang merupakan nutrient anorganik utama yang diperlukan mikroorganisme.

\section{Porositas Media}

Porositas media merupakan faktor penting dalam aplikasi reaktor Biofilter.

Porositas ( () adalah kemampuan suatu batuan untuk menyimpan fluida. Porositas total adalah perbandingan ruang kosong/ pori-pori dalam batuan dengan bulk volume batuan (dinyatakan dalam persen). Porositas dinyatakan sebagai perbandingan ruang kosong /pori-pori dalam batuan dengan keseluruhan volume batuan. Faktor-faktor yang mempengaruhi besarnya porositas adalah : Susunan Batuan, Distribusi Batuan, Sementasi, Kompaksi, dan Angularitas. Besarnya porositas media dalam penelitian ini berturut-turut adalah : Batu Zeolit $=0,505$, Batu apung $=0,510$, dan Pecahan Genteng $=0,500$.

\section{METODOLOGI PENELITIAN}

Penelitian ini menggunakan eksperimen Biofilter aerobik dengan menggunakan variasi media batu zeolit, batu apung, dan pecahan genteng, yang masing-masing dikombinasikan dengan karbon aktif untuk mengolah limbah laundry. Variabel terikat dalam penelitian ini adalah penurunan kadar detergen anionik Linier Alkyl Sulfonat (LAS).

Reaktor Biofilter terbuat dari bahan akrilik dengan ukuran $(15 \times 15 \times 50) \mathrm{Cm}$. Penelitian ini menggunakan 3 (tiga) buah reaktor yang masing-masing berisi media : Zeolit, Batu apung, dan Pecahan genteng. Untuk menahan media dalam reaktor digunakan plat perforated. Porositas media penyangga berturut turut adalah Zeolit $=0,505$, Batu apung $=0,510$, dan Pecahan Genteng = 0,500 . Penambahan media karbon aktif di atas media utama dilakukan dengan tujuan untuk mereduksi bau dan sebagai media filtrasi sehingga menghasilkan efluen yang jernih.

Sampel terolah dalam penelitian ini adalah limbah laundry berasal dari wilayah Desa Bedali Kecamatan Lawang Kabupaten Malang. Aliran dalam reaktor Biofilter dipilih aliran Upflow dengan tujuan untuk memperoleh kestabilan debit dan reduksi TSS sehingga tidak ikut dalam aliran efluen terolah. Pemberian oksigen dilakukan dari sisi samping bawah reaktor dengan menggunakan aerator. Debit aliran dalam reaktor ditentukan sebesar 20 $\mathrm{ml} /$ menit, sehingga waktu tinggal air limbah dalam reaktor adalah selama 6 jam. Desain Reaktor Biofilter dalam penelitian ini seperti terlihat dalam gambar 4 sebagai berikut : 


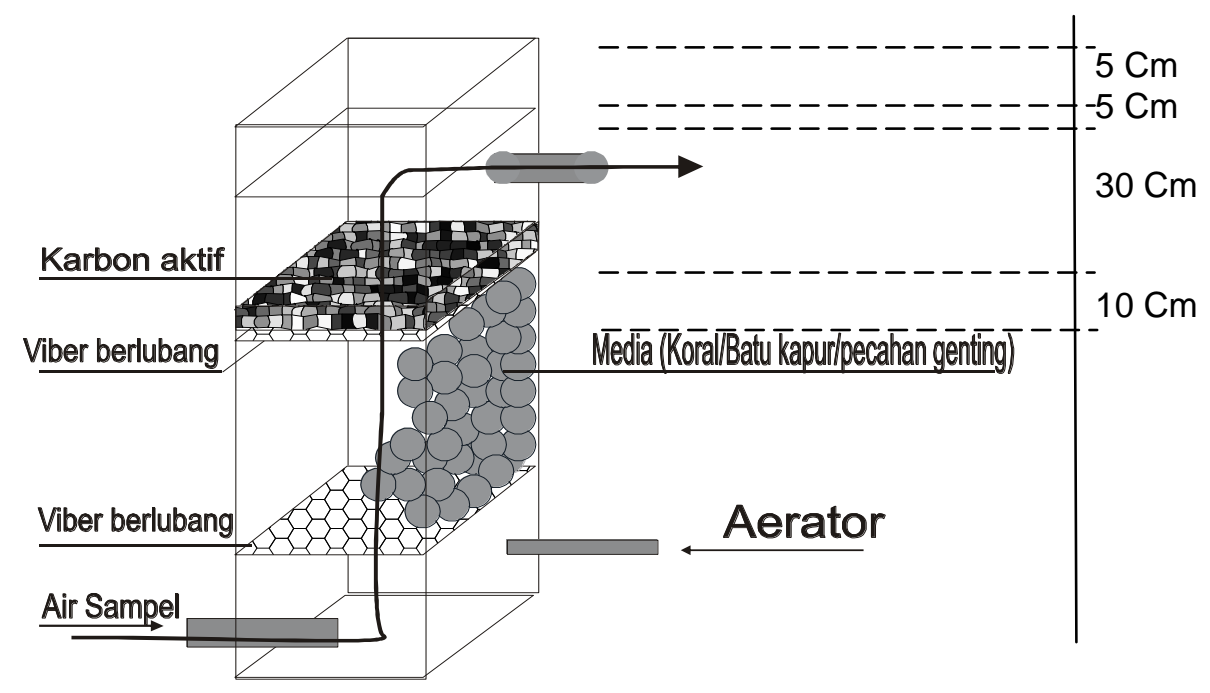

Gambar 4 : Rancangan Reaktor Biofilter Aerobik

Alat dan bahan penunjang yang digunakan dalam penelitian ini adalah :

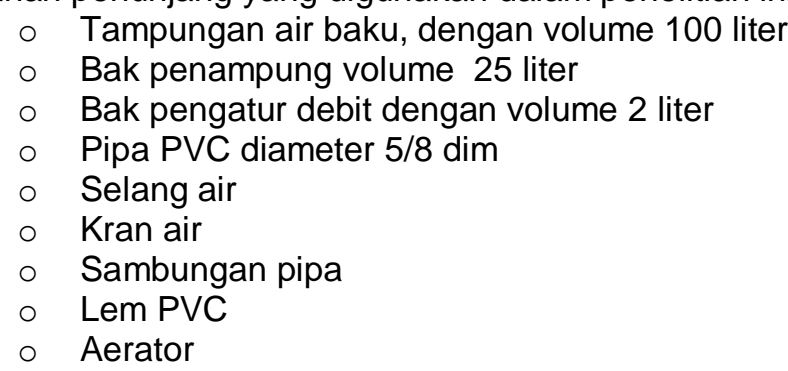

Langkah kerja penelitian adalah sebagai berikut :

1. Mengisi bak penampung air limbah cair dari usaha jasa laundry

2. Air limbah dipompa keatas menuju bak tampung, setinggi $146 \mathrm{Cm}$, melalui pipa PVC.

3. Pengambilan sampel awal untuk mengukur kandungan detergen sebelum terolah

4. Pengaliran air limbah menuju bak pengatur debit dengan kontrol stop kran selanjutnya menuju reaktor Biofilter dengan menggunakan selang.

5. Air limbah limpahan dari bak pengatur debit ditampung dan dinaikkan lagi menuju ke bak tampungan atas

6. Air limbah masuk dengan aliran upflow dan dilakukan aerasi menggunakan aerator.

7. Melakukan proses aklimatisasi reaktor sampai tumbuh mikroorganisme pada media selama 2 minggu

8. Setelah kondisi steady maka dilakukan pengampilan sampel efluen terolah dari masingmasing reaktor untuk selanjutnya dilakukan pengukuran kandungan detergen LAS

Analis parameter detergen
dilakukan dengan menggunakan
Metode Methylene Blue Active
Substances (MBAS) untuk mengukur
surfaktan anionik (APHA AWWA 1998).
Kinerja Biofilter diukur dengan
membandingkan efisiensi penurunan
kandungan detergen pada masing-
masing reaktor dengan menggunakan
variasi media zeolit, batu apung, dan
pecahan genteng dikombinasikan
dengan karbon aktif. Analisis data
disajikan dalam bentuk grafik untuk
membandingkan efisiensi kinerja
masing-masing media.




\section{HASIL DAN PEMBAHASAN}

Hasil percobaan Biofilter aerobik untuk mereduksi konsentrasi detergen pada air limbah laundry diperoleh efisiensi seperti pada tabel 1 sebagai berikut :

Tabel 1. Efisiensi Reduksi Detergen Limbah Laundry

\begin{tabular}{|l|l|l|l|l|}
\hline $\begin{array}{l}\text { No } \\
\text { Percob }\end{array}$ & Jenis Media & $\begin{array}{l}\text { Detergen } \\
\text { Influen } \\
\text { (mg/l) }\end{array}$ & $\begin{array}{l}\text { Detergen } \\
\text { Efluen } \\
\text { (mg/l) }\end{array}$ & $\begin{array}{l}\text { Efisiensi } \\
(\%)\end{array}$ \\
\hline P1 & Zeolit + Karbon aktif & 89,25 & 55,50 & 38 \\
P1 & Batu apung + Karbon aktif & 89,25 & 19,40 & 78 \\
P1 & Pecahan genteng + Karbon aktif & 89,25 & 9,625 & 89 \\
P2 & Zeolit + Karbon aktif & 142,00 & 12,30 & 91 \\
P2 & Batu apung + Karbon aktif & 142,00 & 4,525 & 97 \\
P2 & Pecahan genteng + Karbon aktif & 142,00 & 1,375 & 99 \\
P3 & Zeolit + Karbon aktif & 118,20 & 25,975 & 78 \\
P3 & Batu apung + Karbon aktif & 118,20 & 12,275 & 90 \\
P3 & Pecahan genteng + Karbon aktif & 118,20 & 3,875 & 97 \\
\hline
\end{tabular}

Selanjutnya untuk mendeskripsikan kemampuan media biofilter dalam mereduksi kandungan detergen ditunjukkan dalam gambar 5 dan gambar 6 seperti berikut:

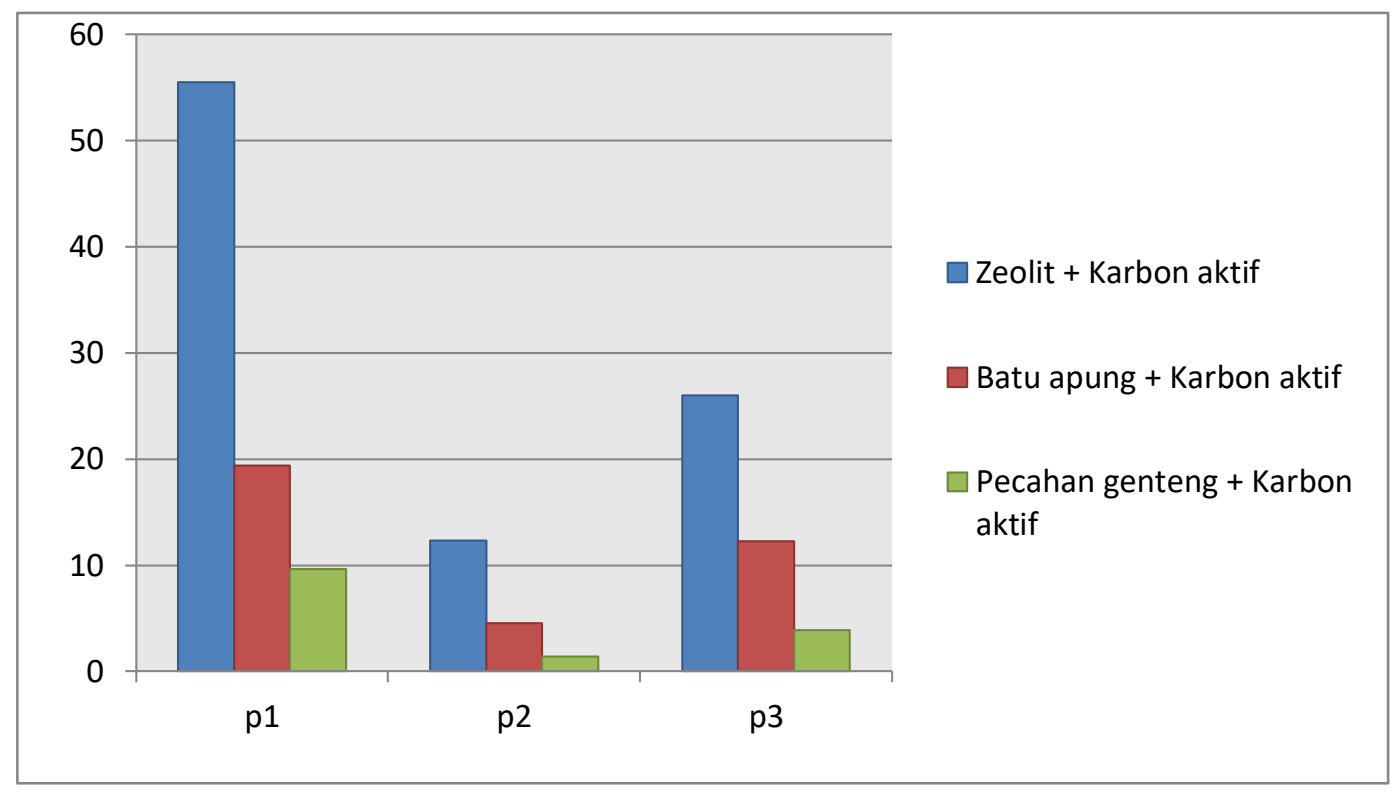

Gambar 5 : Konsentrasi detergen efluen (mg/l) pada berbagai variasi media

Gambar 5 menunjukkan kemampuan reaktor Biofilter aerobik dalam menurunkan kandungan detergen dengan menggunakan media yang bervariasi terpadukan media karbon aktif. Reduksi konsentrasi detergen untuk masing-masing percobaan menunjukkan bahwa kemampuan biofilter aerobik dipengaruhi oleh media yang digunakan. Jenis media pecahan genteng terpadukan karbon aktif merupakan media yang mampu mereduksi konsentrasi detergen paling besar dalam penelitian ini. Pengulangan percobaan menunjukkan bahwa proses kinerja biofilter aerobik semakin baik. Hal ini dipengaruhi oleh pertumbuhan mokroorganisme yang semakin optimal melekat pada media penyangga yang digunakan. Konsentrasi detergen termasuk substrat yang lain menjadi sumber makanan bagi tumbuhnya mikroorganisme.

Kumpulan mikroorganisme (biofilm) yang melekat pada media melakukan proses degradasi detergen termasuk bahan organik yang terlarut. Mikroorganisme terdiri dari kumpulan bakteri, ganggang, jamur, dan protozoa yang memanfaatkan komponenkomponen terlarut dalam limbah sebagai 
substrat/bahan makanan terutama senyawa karbon. Rantai atom karbon pada gugus alkil yang terdapat pada detergen diuraikan sehingga menjadi terputus rantainya. Hal inilah yang menjadikan konsentrasi surfaktan detergen dalam air limbah menjadi berkurang bahkan habis dimakan oleh mikroorganisme. Mekanisme proses ini terjadi dalam reaktor biofilter aerobik.

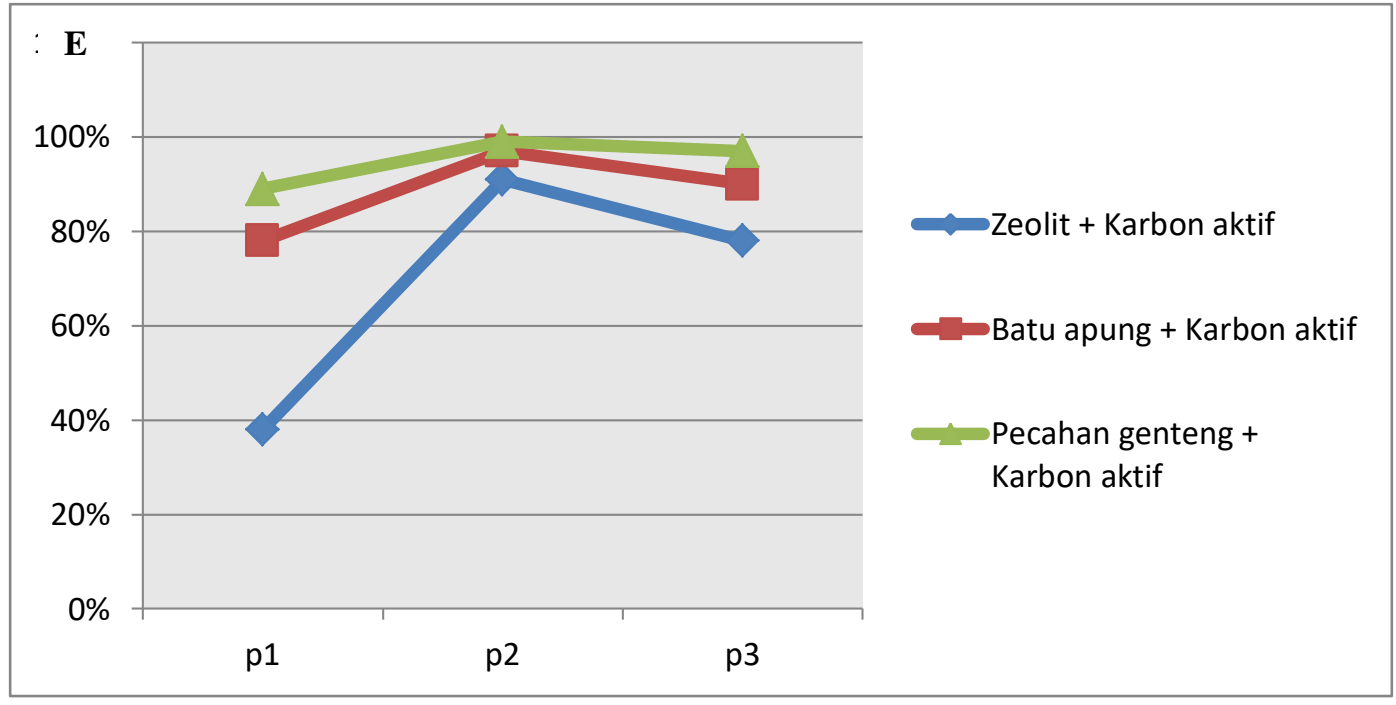

Gambar 6 : Grafik Efisiensi Reduksi Konsentrasi Detergen

Fluktuasi reduksi konsentrasi detergen untuk masing-masing percobaan dipengaruhi oleh kinerja lapisan biofilm yang tumbuh. Terjadi penurunan detergen yang drastis pada percobaan kedua (efisiensi maksimum) menunjukkan bahwa kinerja mikroorganisme aerobik terjadi secara optimal (gambar 6). Namun terjadi penurunan efisiensi pada percobaan ketiga. Hal ini disebabkan karena lapisan biofilm yang semakin tebal menyebabkan penetrasi oksigen untuk mensuplai lapisan biofilm terdalam sehingga menyebabkan kematian mikroorganisme dan akhirnya mengelupas, (Slamet \&Masduki, 2000). Lapisan biofilm selanjutnya tumbuh kembali untuk selanjutnya mendegradasi bahan organik termasuk detergen yang terlarut dalam air limbah laundry.

Berdasarkan grafik pada gambar 6 diperoleh bahwa efisiensi tertinggi reduksi detergen dalam penelitian ani adalah pada aplikasi biofilter dengan menggunakan media pecahan genteng terpadukan karbon aktif, yaitu rata-rata sebesar $96 \%$. Pengulangan percobaan yang merupakan proses lanjutan secara kontinu menunjukkan kinerja reaktor yang stabil pada media ini. Pecahan genteng memiliki permukaan sedemikian rupa sehingga mikroorganisme dapat tumbuh melekat secara optimal. Sedangkan media zeolit menunjukkan reduksi yang terendah disebabkan karena permukaan media ini yang lebih halus. Hal ini sejalan dengan aplikasi yang dilakukan di berbagai negara dengan menggunakan media aktif yang telah dikembangkan walaupun dengan ukuran media yang lebih kecil. Penelitian Said (2006) dengan menggunakan biofilter aerobik mampu menurunkan kandungan detergen secara optimal. Hasil efisiensi yang besar pada penelitian ini menunjukkan bahwa kinerja reaktor biofilter sangat baik. Ini berarti bahwa konsentrasi detergen dalam bentuk LAS mampu didegradasi oleh mikroorganisme sehingga dihasilkan efluen yang tidak mencemari air permukaan.

Penambahan media karbon aktif dalam Biofilter berfungsi untuk memberikan kontribusi pada proses degradasi konsentrasi detergen dan menyerap bau. Bau pada limbah laundry berasal dari senyawa organik yang sengaja ditambahlan untuk memberikan aroma pewangi dan pelembut pakaian. Dari hasil percobaan terlihat bahwa pada media karbon aktif juga tumbuh mikroorganisme yang mendegradasi bahan organik. Selain itu karbon aktif berfungsi secara fisik sebagai media filter sehingga menghasilkan efluen yang jernih. Efluen yang dihasilkan berupa air olahan yang jernih dan tidak berbau.

Media batu apung menunjukkan efisiensi yang juga baik yaitu sebesar rata- 
rata $92 \%$. Pertumbuhan mikroorganisme dipengaruhi oleh oleh media pada reaktor biofilter. Media dengan permukaan yang kasar sangat efektif digunakan sebagai tempat menempelnya mikroorganisme. Faktor yang berkaitan dengan media adalah porositas. Kemampuan alir fluida dipengaruhi oleh porositas media yang dilewati. Berdasarkan jenis media yang digunakan rata-rata memiliki porositas sebesar 5,005 memberikan hasil reduksi detergen yang hampir sama. Peningkatan beban konsentrasi detergen pada influen justru menunjukkan hasil kinerja biofilter yang lebih baik. Hal ini terjadi karena pertumbuhan mikroorganisme berada pada kondisi optimal dalam mendegradasi bahan organik termasuk detergen LAS.

Berdasarkan hasil penelitian ini dapat direkomendasikan kepada pengusaha laundry khususnya di area permukiman untuk melakukan pengolahan limbah yang dihasilkan dengan menggunakan reaktor biofilter sederhana. Pemanfaatan media terpilih dapat menggunakan bahan bahan yang mudah diperoleh dan harganya murah. Aplikasi biofilter dapat dilakukan dengan menggunakan bahan paralon bekas secara horisontal untuk memudahkan pengaliran atau menggunakan bak dari bahan bekas pada area yang sempit. Upaya ini harus dilakukan untuk menjaga kualitas air permukaan dan pengusaha terhindar dari komplain masyarakat.

\section{Kesimpulan}

Berdasarkan hasil pembahasan maka kesimpulan dalam penelitian ini bahwa biofilter aerobik dengan menggunakan media pecahan genteng terpadukan karbon aktif mampu mereduksi konsentrasi detergen pada limbah laundry dengan tingkat efisiensi rata-rata sebesar $96 \%$.

\section{Saran}

Direkomendasikan kepada para pengusaha laundry untuk mengaplikasikan teknologi biofilter aerobik sehingga limbah yang dihasilkan tidak mencemari air permukaan dan tidak dokomplaon oleh masyarakat.

\section{DAFTAR PUSTAKA}

APHA AWWA. 1998. Standard Methods for the Examinatinos of Water and Wastewater , $20^{\text {th }}$ edition. Washington.

Connel \& Miller. 1995. Kimia dan Ekotoksikologi Pencemaran, diterjemahkan oleh Yanti Koestoer. Penerbit Universitas Indonesia.

Ifadah, S. M. \& Sugito .2012. Kinerja IPAL Biofilter untuk Pengolahan Air Limbah Domestikdi UPT Puskesmas Janti Kota Malang.

Metcalf \& Eddy. 2004. Wastewater Engineering Treatment and Reuse, Fourth Edition. New York. Mc Graw Hill Inc.

Said, Nusa Idaman. 2006. Instalasi Pengolahan Limbah Rumah Sakit. Kelompok Teknologi Pengolahan Air Bersih dan Air Limbah, Pusat Pengkajian dan Penerapan Lingkungan, Jakarta, BPPT.

Siti komariah \& Sugito. Perencanaan IPAL Biofilte di UPTD Kesehatan PuskesmasGondangwetan Kabupaten Pasuruan . Jurnal Teknik WAKTU ISSN : 1412-1867, Volume 9 N0 2, Juli 2011. Slamet \& Masduki. 2000. Satuan Proses. Jurusan Teknik Lingkungan FTSP ITS Surabaya. 